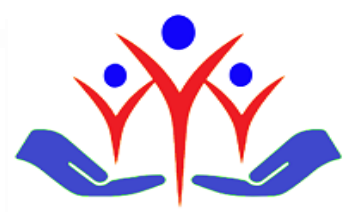

Research Article

\title{
Knowledge, attitudes, and behaviors of medical students regarding HPV and HPV vaccine
}

\author{
Tıp fakültesi öğrencilerinin HPV ve HPV aşısı ile ilgili bilgi, tutum ve davranışları
}

\author{
(D) Haci Ozturk Sahina, (D Ozgur Ozerdogan ${ }^{\mathbf{b}}$, Mehmet Nuri Duran ${ }^{\mathbf{a}}$ \\ Department of Public Health, School of Medicine, Canakkale Onsekiz Mart University, Canakkale, Turkey
}

\begin{abstract}
Introduction: HPV (Human papilloma virus) is the most common sexually transmitted infection and constitutes an important part of cancers for which infectious agents are blamed in its ethology. The most important duty of informing the public about HPV and the HPV vaccine with a high protection rate belongs to doctors. The curriculum and scope of this subject in medical education in our country is uncertain. We aimed to determine the knowledge, attitudes, and behaviours of our students about HPV and the HPV vaccine before the internship and to find out the change in their knowledge, attitudes, and behaviour status after the internship. Method: The population of the study consists of a total of 257 third and sixth grade students studying in the Faculty of Medicine at Çanakkale Onsekiz Mart University during the 2018-2019 academic year. A questionnaire, including questions and suggestions about sociodemographic characteristics, and knowledge, attitudes and behavioural status about HPV infection and the HPV vaccine, was administered under supervision to third and sixth grade students between April and June 2019 without specifying their name and surname. Chi-square test was used for statistical evaluation. For statistical significance, $\mathrm{p}<0.050$ was accepted.

Results: 108 third grade and 91 sixth grade students participated in our study. Although HPV is known to play a role in the ethology of cervical cancer and anogenital warts $(91 \%, 91.2 \%)$, this awareness was as low as $35.4 \%, 37.9 \%$ and $38.8 \%$, respectively, in penis, anus and head and neck cancers. The knowledge level was statistically significant in favour of the sixth-grade students $(\mathrm{p}<0.001)$. When the attitudes and behaviours of the students were examined, the frequency of having the HPV vaccine was $4.5 \%$. It was observed that the frequency of the idea of vaccination among the female students was higher than that of the male students $(61.3 \%$, $18.1 \%)$. No statistically significant difference was found among the possible variables that could affect the need for the HPV vaccine when compared according to the gender, grade, and the educational status of the mother or father $(\mathrm{p}>0.05)$. The reason why the students did not have the HPV vaccine was related to the fact that they found the vaccine expensive and did not consider it necessary. Only $46.7 \%$ of the sixth-grade students thought that they could give their patients enough information about the HPV virus and vaccine when they graduated.

Conclusion: The frequency of vaccination in our country is very low even among doctors. Training strategies should be developed to enable doctors to graduate with full knowledge of HPV and the HPV vaccine with multidimensional training programs.

Keywords: Papillomavirus infections, internship and residency, papillomavirus vaccines, medical students, health knowledge, attitudes
\end{abstract}

\section{$\ddot{O} z$}

Giriş: HPV (Human papilloma virüs) seksüel yolla bulaşan en sık enfeksiyondur ve etiyolojisinde enfeksiyon ajanlarının suçlandığ kanserlerin önemli bir bölümünü oluşturmaktadır. HPV ve koruyuculuk oranı bir hayli yüksek HPV aşısı ile ilgili toplumu bilgilendirmede en önemli görev doktorlara düşmektedir. Ülkemizde tıp eğitiminde bu konu ile ilgili müfredat programı ve kapsamı belirsizdir. Biz de öğrencilerimizin staj öncesi HPV ve HPV aşısı hakkındaki bilgi, tutum ve davranışlarını ve staj sonrası konu ile ilgili değişim durumlarını saptamayı amaçladık.

Yöntem: Çalışmanın evrenini Çanakkale Onsekiz Mart Üniversitesi Tıp Fakültesi 2018-2019 Bahar Yarıyılı Eğitim Öğretim Döneminde eğitim almakta olan 3. ve 6. sınıf toplam 257 öğrenci oluşturmaktadır. 3. ve 6.sınıf öğrencilerine, Nisan-Haziran 2019 tarihleri arasında, gözetim altında, ad soyadı belirtilmeden, sosyodemografik özellikleri ve HPV enfeksiyonu ile HPV aşısı hakkında bilgi, tutum, davranış durumunu sorgulayan soruları/önermeleri içeren soru formu uygulanmıștır. İstatistiksel değerlendirmede ki-kare testi kullanılmıștır. İstatistiksel anlamlılık için p $<0,05$ kabul edilmiștir.

Bulgular: Çalışmamıza 3. Sınıf 108, 6. Sınıf 91 öğrenci katılmıştır. Bilgi düzeyinde HPV’nin serviks kanseri ve anogenital siğil etiyolojisinde rol oynadığının yüksek oranda bilinmesine rağmen (\%91 ve \%91,2); penis, anüs ve baş boyun kanserinlerinde bu farkındalık sırasıyla $\% 35,4, \% 37,9$ ve $\% 38,8$ gibi düşük oranlardaydı. Bilgi düzeyi 6. sınıf öğrencileri lehine istatistiksel olarak anlamlıydı(p<0,001). Öğrencilerin tutum ve davranış durumu incelendiğinde HPV aşısı yaptırmış olma sıklığı \% 4,5’ti. Kız öğrencilerinde aşıyı yaptırma düşüncesinin erkek öğrencilerden daha yüksek olduğu görüldü $(\% 61,3, \% 18,1)$. HPV aşısının gereklilik düsüncesini etkileyebilecek olası değiskenler arasında düsündüğümüz cinsiyet, sınıf, anne veya babanın lise ve yüksek okul eğitim durumuna göre karşılaştırıldığında istatistiksel olarak anlamlı fark saptanmadı ( $>>0,05)$. HPV aşısını yaptırmayan öğrencilerin yaptırmama nedeni olarak ilk sırayı pahalı olması ve gerekli görmeme almaktaydı. Altıncı sınıf öğrencilerinin sadece \% 46,7'sinin mezun olduğunda HPV virüsü ve aşısı hakkında hastalarına yeterli bilgiyi verebileceğini düşündüğü ifade etti.

Sonuç: Ülkemizdeki aşılanma sıklığı hekimler arasında bile çok düşüktür. Birincil önceliği koruyucu hekimlik olan aile hekimi adayları, HPV ve aşısı hakkında çok yönlü eğitim programları ile tam bir bilgi birikimi ile mezun olmalıdır.

Anahtar kelimeler: Papilloma virüsü enfeksiyonları, ön hekimlik, papilloma virüsü aşıları, tıp öğrencileri, sağlık bilgisi, tutumlar

\begin{tabular}{|c|c|c|c|c|}
\hline Received & Accepted & Published Online & Corresponding Author & E-mail \\
\hline October 28, 2019 & October 15, 2020 & December 16, 2020 & Haci Ozturk SAHIN, MD & ozturksahin@ @omu.edu.tr \\
\hline Correspondence & $\begin{array}{l}\text { Dr. Hac1 Öztürk ŞAHIN, Barbaros Mah.Prof.Dr.Sevim Buluç Sok.Terzioğlu yerleşkesi.B Blok. No:4 } \\
\text { Çanakkale-Turkey }\end{array}$ \\
\hline
\end{tabular}




\section{Introduction}

Human papilloma virus (HPV) is the most common sexually transmitted disease [1]. Highly oncogenic types are responsible for the vast majority of cancers among more than 200 types. While HPV is responsible for almost all of cervical cancers, it is also the etiologic factor for $91 \%$ of anal cancers, $75 \%$ of vaginal cancers, $63 \%$ of penile cancers, $69 \%$ of vulvar cancers and $60 \%$ of oro-pharyngeal cancers [2,3]. Coexistence of HPV and prostate cancer was found to be $20 \%$ in a new study investigating their relationship and the difference between study and control group was reported to be significant [4].

While Gardasil and Cervarix are protective against HPV 16 and 18, the latest product, Gardasil 9 is protective against 9 HPV types which are responsible for cervical, vulvar, vaginal and anal cancers [5]. While adverse effects of the vaccine are negligible, protective effect is about 100\% $[6]$.

Awareness of HPV-related ano-genital skin lesions and cancers are increasing worldwide [7]. Although this awareness seems to be associated with level of education and income, it varies among countries depending on its social structure, degree of conservatism and the age of the first sexual intercourse. Studies have been conducted in different parts of Turkey investigating the level of knowledge about HPV infection and vaccine [8$10]$.

The most important factor in raising awareness and consciousness is undoubtedly the sufficient level of knowledge of the health personnel who have undertaken this task. In the survey conducted with medical students, who are the future doctors, it was reported that only $40 \%$ of them felt well-informed about the vaccine and could provide comfortable counselling to their patients [11]. We aimed to examine the knowledge, attitudes, and behaviours of doctors, who are in a significant position in terms of informing and guiding the society about HPV and HPV-related diseases and the importance of the HPV vaccine, and to find out their gradual change in their knowledge, attitudes, and behaviours during their medical education. In this way, we wanted to contribute to the evaluation of our medical education through constructive self-criticism.

\section{Methods}

\section{Study type and universe}

This is a descriptive epidemiologic study. The study universe is composed of the grade 3 and 6 students who were attending to Canakkale Onsekiz Mart University, Medical School during 2018-2019 spring semester. There were 134 grade 3 students and 123 grade 6 students at the date of March 08, 2019. The whole universe was aimed to be reached before sample selection and a total of 199 students including 108 grade 3 and 91 grade 6 students (77.4\% of the whole population) were reached during the study. The students who could not be reached at the medical school and who did not agree for participation were excluded.

\section{Study design}

Data were collected through a questionnaire form which was created by the researchers and included questions/suggestions inquiring knowledge, attitudes and behaviors about HPV infection and HPV vaccine. Grade 3 and 6 students were taken in a room so as not to contact with each other and filled out the questionnaire form under supervision within 15-20 min without including identity data. The procedure was applied to grade 3 students in classrooms and to grade 6 students at their workplace.

\section{Ethical approval, informed consent and permissions}

Ethics committee approval was obtained prior to the study (date: 13.03.2019, decision number: 2019-06). The volunteer participants had been informed about the aim and the method of the study by the researchers before written and verbal consent was obtained.

\section{Statistical analysis}

Data were analyzed by using SPSS (SPSS Inc., Chicago, IL, USA) version 20.0 and expressed as number, percent, mean, standard deviation, median, minimum and maximum values. Chi-square test was used for categorical variables. A p level of $<0.050$ was accepted as statistically significant.

\section{Results}

Mean age of the participants was 22.3 \pm 2.1 (Median: 23, Minimum-Maximum:18-29) and 21.2 \pm 1.5 (Median: 21, Minimum-Maximum: 18-27) for grade 3 students, 24.4 \pm 1.1 (Median: 24, Minimum-Maximum:23-29) for grade 6. Of the participants, 58.8\% were female and 54.3\% were grade 3 students, $43.1 \%$ were graduates of Anadolu high school and $15.2 \%$ were graduates of private school. Education level of mothers was high school and above in $56.8 \%$ and this ratio was $74.9 \%$ for fathers. Of the students, $68.7 \%$ did not smoke at any stage of their lives. Vast majority (71.4\%) of the participants had been living in provinces during a long time of their lives (Table 1). 
Table 1. Socio-demographic characteristics of the study group

\begin{tabular}{|c|c|}
\hline Variables & n $(\%)$ \\
\hline \multicolumn{2}{|l|}{ Gender $(n=199)$} \\
\hline Female & $117(58.8)$ \\
\hline Male & $82(41.2)$ \\
\hline \multicolumn{2}{|l|}{ Grade $(n=199)$} \\
\hline Three & $108(54.3)$ \\
\hline Six & $91(45.7)$ \\
\hline \multicolumn{2}{|l|}{ High school $(n=195)$} \\
\hline Anadolu college & $84(43.1)$ \\
\hline Science college & $62(31.8)$ \\
\hline Anadolu Teachers college & $33(16.9)$ \\
\hline Others & $16(8.2)$ \\
\hline \multicolumn{2}{|l|}{ High school $(n=198)$} \\
\hline Private & $30(15.2)$ \\
\hline State & $168(84.8)$ \\
\hline \multicolumn{2}{|l|}{ Education level of the mother $(n=199)$} \\
\hline Below high school & $86(43.2)$ \\
\hline High school and above & $113(56.8)$ \\
\hline \multicolumn{2}{|l|}{ Education level of the father $(n=199)$} \\
\hline Below high school & $50(25.1)$ \\
\hline High school and above & $149(74.9)$ \\
\hline \multicolumn{2}{|l|}{ Smoking status $(\mathrm{n}=198)$} \\
\hline Never smoked & $136(68.7)$ \\
\hline Currently smoking & $46(23.2)$ \\
\hline Quit smoking & $16(8.1)$ \\
\hline \multicolumn{2}{|l|}{ The place where the participant lived the longest $(n=199)$} \\
\hline Province & $142(71.4)$ \\
\hline County/village/town & $57(28.6)$ \\
\hline
\end{tabular}

$\mathrm{n}=$ Number, $\%=$ Column percentage

When the answers given to the statements expressing the level of knowledge about HPV and the HPV vaccine were examined, $85.7 \%$ of the thirdgrade students and $96.7 \%$ of the sixth-grade students stated that HPV was responsible for anogenital warts, whereas those who thought that HPV caused cervical cancer were $83.2 \%$ and $98.9 \%$, respectively. As a result of these propositions, a statistically significant difference was found in favour of the sixth-grade students in the grade variable comparison ( $\mathrm{p}<0.05$ ). While $35.4 \%$ of the participants thought that HPV could cause penile cancer, $37.9 \%$ of them thought that it could cause anus cancer and $38.8 \%$ stated that it could cause head and neck cancer. There was a statistically significant difference among the correct answers in favour of the sixth-grade students ( $\mathrm{p}<0.001)$. Awareness of the relationship between HPV virus and vagina and prostate cancer was generally found in $40.3 \%$ and $12.3 \%$ of the participants, respectively (Table 2 ).

When the attitudes and behaviors of the students were examined, only $4.5 \%$ of them had the HPV vaccine. $43.6 \%$ of those who did not have the HPV vaccine thought of getting the vaccine. There was no significant difference between the third and sixth grade students in the situation of having had the vaccine or thinking about getting it. However, when we examine those thinking about having the vaccine based on gender, $61.3 \%$ of the female students answered yes, while this rate was only $18.1 \%$ for the male students. Among the participants who did not have the HPV vaccine, the most common reason for not having it was stated that it was expensive and/or not necessary (Table 3). When factors such as gender, grade, and the educational status of the mother or father, which are the possible variables that could affect the attitudes of the students regarding whether HPV vaccine is necessary or not, were compared, no statistically significant difference was found. (Table 4).

When the knowledge of the participants about the transmission route of HPV was questioned, the third and sixth grade students stated that it was transmitted through sexual intercourse $(54.3 \%, 71.9 \%)$, blood $((30.4 \%, 11.6 \%)$ and dirty toilet use $(10.9 \%, 14.9 \%)$, respectively.

While $91.2 \%$ of the participants, who were considering getting the HPV vaccine, unsurprisingly answered yes to the question 'if I have/had a child, I will/would have my child vaccinated', whereas $57.1 \%$ of those who did not think of having the vaccine or were indecisive interestingly gave a positive answer to the same question. $(\mathrm{P}<0.001)$ (Table 5) 
Table 2. Responses to the suggestions about HPV and HPV vaccine according to grades

\begin{tabular}{|c|c|c|c|c|}
\hline \multirow{2}{*}{ Suggestions } & \multicolumn{4}{|c|}{ Grade } \\
\hline & & Three n (\%) & $\operatorname{Six~} n(\%)$ & $\mathbf{p}$ \\
\hline \multicolumn{5}{|c|}{ HPV is responsible for anogenital verruca } \\
\hline & Yes & $90(85.7)$ & $88(96.7)$ & 0.002 \\
\hline & No & $1(1.0)$ & $2(2.2)$ & \\
\hline & Undecided & $14(13.3)$ & $1(1.1)$ & \\
\hline \multicolumn{5}{|c|}{ HPV causes cervical cancer } \\
\hline & Yes & $89(83.2)$ & $90(98.9)$ & $<0.001$ \\
\hline & No & $3(2.8)$ & $1(1.1)$ & \\
\hline & Undecided & $15(14.0)$ & $0(0.0)$ & \\
\hline \multicolumn{5}{|c|}{ HPV may cause vaginal cancer } \\
\hline & Yes & $47(44.4)$ & $32(35.5)$ & $<0.001$ \\
\hline & No & $21(19.8)$ & $44(48.9)$ & \\
\hline & Undecided & $38(35.8)$ & $14(15.6)$ & \\
\hline \multicolumn{5}{|c|}{ HPV may cause penile cancer } \\
\hline & Yes & $34(32.4)$ & $35(38.9)$ & $<0.001$ \\
\hline & No & $21(20.0)$ & $44(48.9)$ & \\
\hline & Undecided & $50(47.6)$ & $11(12.2)$ & \\
\hline \multicolumn{5}{|c|}{ HPV may cause prostate cancer } \\
\hline & Yes & $20(19.1)$ & $4(4.5)$ & $<0.001$ \\
\hline & No & $35(33.3)$ & $74(82.2)$ & \\
\hline & Undecided & $50(47.6)$ & $12(13.3)$ & \\
\hline \multicolumn{5}{|c|}{ HPV may cause anal cancer } \\
\hline & Yes & $31(29.5)$ & $43(47.7)$ & $<0.001$ \\
\hline & No & $27(25.7)$ & $32(35.6)$ & \\
\hline & Undecided & $47(44.8)$ & $15(16.7)$ & \\
\hline \multicolumn{5}{|c|}{ HPV may cause head and neck cancer } \\
\hline & Yes & $22(21.4)$ & $53(58.9)$ & $<0.001$ \\
\hline & No & $32(31.1)$ & $26(28.9)$ & \\
\hline & Undecided & $49(47.5)$ & $11(12.2)$ & \\
\hline \multicolumn{5}{|c|}{ Condom use is protective against HPV transmission } \\
\hline & Yes & $70(66.7)$ & $54(60.0)$ & 0.074 \\
\hline & No & $18(17.1)$ & $27(30.0)$ & \\
\hline & Undecided & $17(16.2)$ & $9(10.0)$ & \\
\hline \multicolumn{5}{|c|}{ History of sexually transmitted diseases is a risk factor for cervical cancer } \\
\hline & Yes & $95(91.3)$ & 87 (96.7) & 0.214 \\
\hline & No & $1(1.0)$ & $0(0.0)$ & \\
\hline & Undecided & $8(7.7)$ & $3(3.3)$ & \\
\hline \multicolumn{5}{|c|}{ Smoking is a risk factor for cervical cancer } \\
\hline & Yes & $82(78.1)$ & $74(81.3)$ & 0.380 \\
\hline & No & $3(2.9)$ & $5(5.5)$ & \\
\hline & Undecided & $20(19.0)$ & $12(13.2)$ & \\
\hline
\end{tabular}

$H P V=$ Human Papilloma Virus, $n=$ number, \%= Column percentage, $p=$ chi-square test 
Table 3. Responses to the questions about knowledge, attitudes and behavior about HPV and HPV vaccine according to gender and grade

\begin{tabular}{|c|c|c|c|c|}
\hline \multirow[b]{2}{*}{ Variables } & \multicolumn{2}{|c|}{ Gender } & \multicolumn{2}{|c|}{ Grade } \\
\hline & $\begin{array}{c}\text { Female } \\
\text { n }(\%)\end{array}$ & $\begin{array}{l}\text { Male } \\
\text { n }(\%)\end{array}$ & $\begin{array}{l}\text { Three } \\
\text { n }(\%)\end{array}$ & $\begin{array}{c}\text { Six } \\
\text { n }(\%)\end{array}$ \\
\hline \multicolumn{5}{|l|}{ Getting vaccinated against HPV } \\
\hline Yes & $7(6.0)$ & $2(2.4)$ & $5(4.6)$ & $4(4.4)$ \\
\hline No & $110(94.0)$ & $80(97.6)$ & $103(95.4)$ & $87(95.6)$ \\
\hline \multicolumn{5}{|l|}{ The reason for not getting vaccinated against HPV a, b } \\
\hline Being male & $0(0.0)$ & $25(29.8)$ & $10(9.9)$ & $15(16.1)$ \\
\hline Being expensive & $28(25.5)$ & $11(13.1)$ & $11(10.9)$ & $28(30.1)$ \\
\hline Being not covered by the insurance & $21(19.1)$ & $7(8.3)$ & $13(12.8)$ & $15(16.1)$ \\
\hline Not considering it necessary & $31(28.2)$ & $29(34.5)$ & $32(31.7)$ & $28(30.1)$ \\
\hline Having insufficient knowledge about the issue & $17(15.4)$ & $6(7.1)$ & $21(20.8)$ & $2(2.2)$ \\
\hline Not thinking about this issue before, not having time & $8(7.3)$ & $4(4.8)$ & $9(8.9)$ & $3(3.2)$ \\
\hline Considering getting vaccinated in future & $3(2.7)$ & $0(0.0)$ & $2(2.0)$ & $1(1.1)$ \\
\hline Considering it unnecessary due to his/her age & $0(0.0)$ & $1(1.2)$ & $0(0.0)$ & $1(1.1)$ \\
\hline No reason & $2(1.8)$ & $1(1.2)$ & $3(3.0)$ & $0(0.0)$ \\
\hline \multicolumn{5}{|l|}{ Considering getting vaccinated against $\mathrm{HPV}$ a } \\
\hline 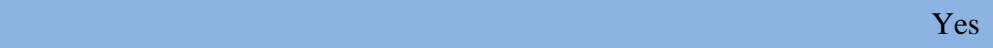 & $68(61.3)$ & $14(18.1)$ & $45(44.6)$ & $37(42.6)$ \\
\hline No & $9(8.1)$ & $32(41.6)$ & $16(15.8)$ & $25(28.7)$ \\
\hline Undecided & $34(30.6)$ & $31(40.3)$ & $40(39.6)$ & $25(28.7)$ \\
\hline \multicolumn{5}{|l|}{ Transmission way of HPV b } \\
\hline Sexual route & $111(64.9)$ & $76(56.7)$ & $100(54.3)$ & $87(71.9)$ \\
\hline With blood & $37(21.6)$ & $33(24.6)$ & $56(30.4)$ & $14(11.6)$ \\
\hline With the use of contaminated toilets & $18(10.5)$ & $20(14.9)$ & $20(10.9)$ & $18(14.9)$ \\
\hline With any body fluids & $0(0.0)$ & $1(0.8)$ & $1(0.6)$ & $0(0.0)$ \\
\hline No idea & $5(3.0)$ & $4(3.0)$ & $7(3.8)$ & $2(1.6)$ \\
\hline \multicolumn{5}{|l|}{ Who is affected from HPV } \\
\hline Only males & $0(0.0)$ & $1(1.2)$ & $0(0.0)$ & $1(1.1)$ \\
\hline Only females & $6(5.1)$ & $4(4.9)$ & $5(4.6)$ & $5(5.5)$ \\
\hline Both males and females & $110(94.0)$ & $74(90.2)$ & $99(91.7)$ & $85(93.4)$ \\
\hline No idea & $1(0.9)$ & $3(3.7)$ & $4(3.7)$ & $0(0.0)$ \\
\hline & $\begin{array}{c}\text { Yes } \\
\mathbf{n}(\%)^{*}\end{array}$ & & & $\begin{array}{l}\text { Undecided } \\
\text { n }(\%)^{*}\end{array}$ \\
\hline I am competent to yield sufficient knowledge to my patients about HPV c & $42(46.7)$ & 22 & & $26(28.9)$ \\
\hline
\end{tabular}

$H P V=$ Human Papilloma Virus, $n=$ Number , \%= Column percentage, *= Line percentage, a: The participants who were not vaccinated against HPV responded this question, $b$ : Participants gave more than one response to this question and the analyses were done with total responses, c: Only grade 6 students responded this suggestion

Table 4. Comparison of socio-demographic variables and considering that HPV vaccine is necessary in the participants who were not vaccinated against HPV

\begin{tabular}{|c|c|c|c|c|}
\hline \multirow[b]{2}{*}{ Variables } & \multicolumn{4}{|c|}{ Considering that HPV vaccine is necessary } \\
\hline & & $\begin{array}{c}\text { No } \\
\text { n }(\%)\end{array}$ & $\begin{array}{c}\text { Yes } \\
\text { n }(\%)\end{array}$ & $\mathbf{p}$ \\
\hline \multicolumn{5}{|l|}{ Gender } \\
\hline & Female & $31(28.2)$ & $79(71.8)$ & 0.118 \\
\hline & Male & $29(39.2)$ & $45(60.8)$ & \\
\hline \multicolumn{5}{|l|}{ Grade } \\
\hline & Three & $32(32.7)$ & $66(67.3)$ & 0.989 \\
\hline & Six & $28(32.6)$ & $58(67.4)$ & \\
\hline \multicolumn{5}{|c|}{ Education level of the mother } \\
\hline & Below high school & $25(30.9)$ & $56(69.1)$ & 0.654 \\
\hline & High school and above & $35(34.0)$ & $68(66.0)$ & \\
\hline \multicolumn{5}{|c|}{ Education level of the father } \\
\hline & Below high school & $11(23.4)$ & $36(76.6)$ & 0.168 \\
\hline & High school and above & $49(35.8)$ & $88(64.2)$ & \\
\hline
\end{tabular}

$H P V=$ Human Papilloma Virus, $n=$ Number, $\%=$ Column percentage, $a$ : The participants who were not vaccinated against HPV responded this question, $p:$ chisquare test 
Table 5. The association between considering to be vaccinated against HPV and getting their children vaccinated against HPV

\begin{tabular}{|c|c|c|c|c|}
\hline \multirow{2}{*}{\multicolumn{2}{|c|}{ Variables }} & \multicolumn{2}{|c|}{ Considering that $\mathrm{HPV}$ vaccine is necessary ${ }^{\text {a }}$} & \multirow[b]{2}{*}{$\mathbf{p}$} \\
\hline & & $\begin{array}{c}\text { Yes } \\
\text { n }(\%)\end{array}$ & $\begin{array}{c}\text { No/Undecided } \\
\text { n }(\%)\end{array}$ & \\
\hline \multicolumn{5}{|c|}{ 'I will/would get my child vaccinated against HPV if I had/will have a child } \\
\hline & Yes & $73(91.2)$ & $60(57.1)$ & $<0.001$ \\
\hline & No & $1(1.2)$ & $3(2.9)$ & \\
\hline & Undecided & $6(7.5)$ & $42(40.0)$ & \\
\hline
\end{tabular}

$H P V=$ Human Papilloma Virus, $n=$ Number, \%= Column percentage, a: The participants who were not vaccinated against HPV responded this question, p: chi-square test

\section{Discussion}

As leaders of the next generation of healthcare providers, it is essential that current medical students should be thoroughly educated about HPV and the HPV vaccine. This becomes even more important, given the proven efficacy of the HPV vaccine. Getting advice from critical healthcare providers is a much more effective and important factor, and it has, thus, been found that the probability of HPV vaccination is 35 times higher $[12,13]$.

In our study, the level of knowledge about HPV and the HPV vaccine increases with the grades of medical faculty. This situation was found to be compatible with the literature [14]. Unfortunately, there are important information gaps regarding HPV and related cancer types. Although it is widely known that HPV is responsible for cervical cancer and anogenital warts, even the level of knowledge of the sixth-grade students regarding vagina, penis, anus, and prostate cancer is less than 50\%. On the other hand, the rate of HPV-related head and neck cancers has increased sharply over the years [15]. Perhaps because of this lack of information, only $18 \%$ of the male students were considering vaccination, although it is widely known that the HPV virus affects both sexes. Although it is known that HPV is transmitted mostly through sexual intercourse, the fact that $30 \%$ of the third-grade students stated that HPV was transmitted by blood and that only $60 \%$ of the sixth-grade students stated that the use of condoms would prevent HPV transmission indicates that a more comprehensive education about the transmission route of the virus is necessary.

When the behavioural status against the HPV vaccine is examined, it is surprisingly low to have the HPV vaccine in our country. While the frequency of vaccination was found to be $4.5 \%$ in our study, it was reported as $5.3 \%$ in a study conducted with sixth grade students in the Faculty of Medicine at Hacettepe University, (Turkey) [16]. In the literature, this rate is given as $21.1 \%$ to $32.1 \%$ among medical faculty students in Brazil and the USA, respectively [17,18]. We know that as of 2017, 71 countries in the world have included the HPV vaccine for girls in the government's routine vaccination program [19], and the vaccine is free in the USA and most European countries. In our country, the HPV vaccine is not yet in the routine vaccination program, and the fact that expensiveness is one of the most frequent answers as a reason for not having it suggests that economic conditions are the determining factors.

Despite the low vaccination schedule, the attitudes towards the HPV vaccine were generally positive. Although the rate of thinking about vaccination is high, especially in women, more than half of those who did not want to have the vaccine or were indecisive had the thought of having their children vaccinated in the future.

Because of the innovative and multimodal curriculum developed by Schnaith [20] on HPV and the HPV vaccine, it was determined that the belief of medical students about the fact that the HPV vaccine should be mandatory increased, and that they could subsequently communicate more easily with parents who were hesitant about vaccination. Only $46.7 \%$ of our students see that they can give their patients enough information about this virus.

\section{Limitations}

Since the survey was conducted in a medical school, this study's results cannot be considered as a representative of all the medical faculties in Turkey in terms of the level and scope of education offered to students. This study was conducted in a single medical school with a small sample size, which limits generalization. However, we do not think that the students of our institution are socioeconomically different from other medical faculty students, and the data reported from our country are similar to the present results. As in all survey studies, there may be risks such as being affected by the responses of those who choose not to participate, which may affect our results.

\section{Conclusion}

Frequency of vaccination against HPV is very low even among physicians although HPV vaccine is included in routine vaccination schedule in many Western countries. When the results of our study and the literature are evaluated together, we think that it is necessary to design multidimensional training programs for the HPV virus and vaccine in medical school education. 


\section{Conflict of interest: None}

\begin{tabular}{|c|l|l|}
\hline \multicolumn{2}{|c|}{ Author Contributions } & Author Initials \\
\hline SCD & Study Conception and Design & HOS, MND \\
\hline AD & Acquisition of Data & OO, MND \\
\hline AID & Analysis and Interpretation of Data & OO \\
\hline DM & Drafting of Manuscript & HOS,OO \\
\hline CR & Critical Revision & HOS,OO, MND \\
\hline
\end{tabular}

Financial support: None

\section{References}

1. Centers for Disease Control and Prevention. Genital HPV infection-fact sheet.2016. Available at: http://www.cdc.gov/std/hpv/stdfacthpv.htm (Access date: August 2, 2019)

2. Centers for Disease Control and Prevention (CDC) Human papillomavirus-associated cancers - United States, 2004-2008. MMWR Morb Mortal Wkly Rep 2012;61:258-61. Available at: https://www.cdc.gov/mmwr/preview/mmwrhtml/mm6115a2.htm (Access date: April 20, 2012)

3. Hartwig S, Syrjanen S, Dominiak Felden G, Brotons M, Castellsague X. Estimation of the epidemiological burden of human papillomavirusrelated cancers and non-malignant diseases in men in Europe: a review. BMC Cancer. 2012;12:30. https://doi.org/10.1186/1471-2407-12-30

4. Martinez Fierro ML, Leach RJ, Gomez Guerra LS, Garza-Guajardo R, Johnson Pais T, Beuten J, et al. Identification of viral infections in the prostate and evaluation of their association with cancer. BMC Cancer. 2010;10:326. https://doi.org/10.1186/1471-2407-10-326

5. Centers for Disease Control and Prevention. HPV vaccine information for clinicians. 2016. Available at: https://www.cdc.gov/vaccines/news/newsltrs/imwrks/2019/2019-07.html (Access date: August 2, 2019)

6. Brotherton JML, Bloem PN. Population-based HPV vaccination programs are safe and effective: 2017 update and the impetus for achieving better global coverage. Best Pract Res Clin Obstet Gynaecol. 2018;47:42-58. http://dx.doi.org/10.1016/j.bpobgyn.2017.08.010

7. Blasi PR, King D, Henrikson NB. HPV Vaccine Public Awareness Campaigns: An Environmental Scan. Health Promot Pract 2015;16(6):897905. https://doi.org/10.1177\%2F1524839915596133

8. Ersan G, Kose S, Gunes H, Ozkan M. Knowledge and awareness of female sex workers towards human papillomavirus infection in Turkey. Cent Eur J Public Health 2012;20(3):219-22. https://www.ncbi.nlm.nih.gov/pubmed/23285524

9. Ozyer S, Uzunlar O, Ozler S ,Kaymak O, Baser E, Gungor T , et al. Awareness of Turkish female adolescents and young women about HPV and their attitudes towards HPV vaccination. Asian Pac J Cancer Prev 2013;14(8):4877-81. http://dx.doi.org/10.7314/apjcp.2013.14.8.4877

10. Dursun P, Altuntas B, Kuscu E, Ayhan A. Women's knowledge about human papillomavirus and their acceptance of HPV vaccine. Aust N Z J Obstet Gynaecol 2009;49(2):202-6. http://dx.doi.org/10.1111/j.1479-828X.2009.00947.x

11. Afonso NM, Kavanagh MJ, Swanberg SM, Schulte JM, Wunderlich T, Lucia VC. Will they lead by example? Assessment of vaccination rates and attitudes to human papilloma virus in millennial medical students. BMC Public Health 2017;17(1):35. http://dx.doi.org/10.1186/s12889-016-3969-x.

12. Gilkey MB, Moss JL, Coyne-Beasley T, Hall ME, Shah PD, Brewer NT. Physician communication about adolescent vaccination: How is human papillomavirus vaccine different? Prev Med 2015;77:181-5. https://doi.org/10.1016/j.ypmed.2015.05.024

13. Kulczycki A, Qu H, Shewchuk R. Primary Care Physicians' adherence to guidelines and their likelihood to prescribe the human papillomavirus vaccine for 11- and 12-year-old girls. Womens Health Issues 2016; 26(1):34-9. https://doi.org/10.1016/j.whi.2015.07.012

14. Wiley R, Shelal Z, Urbauer D, Bernard C, Ramondetta L. Relationship between intent to vaccinate and the education and knowledge of human papillomavirus among medical school faculty and students in Texas. Tex Med. 2019;115(1):e1. https://ncbi.nlm.nih.gov/30601572/

15. Luryi, AL, Yarbrough, WG, Niccolai, LM, Roser S, Reed SG, Nathan CA, et al. Public awareness of head and neck cancers: a cross-sectional survey. JAMA Otolaryngol Head Neck Surg 2014;140(7):639-46. https://doi:10.1001/jamaoto.2014.867

16. Cesmeci Y, Koylu B, Sulaiman J, Sancak E, Senel S, Baki HE , et al. HPV infection and HPV vaccine through the eyes of interns. Turkish J Gynecol Oncol 2015;18(3):85-92. Available at: https://dergipark.org.tr/tr/pub/trsgo/issue/36053/404733 (Access date: January 30,2016)

17. Daniel CL, McLendon L, Green CL, Anderson KJ, Pierce JY, Perkins A, Beasley M. HPV and HPV vaccination knowledge and attitudes among medical students in Alabama. J Cancer Educ 2019. https://doi:10.1007/s13187-019-01613-3

18. Wanderley MDS, Sobral DT, Levino LA, Marques LA, Feijó MS, Aragão NRC. Students' HPV vaccination rates are associated with demographics, sexuality, and source of advice but not level of study in medical school. Rev Inst Med Trop Sao Paulo 2019;61:e70. https://doi.org/10.1590/s1678-9946201961070

19. Human papillomavirus vaccines: WHO position paper, May 2017. Wkly Epidemiol Rec. 2017;92(19):241-68. English, French. https://apps.who.int/10665/255354

20. Schnaith AM, Evans EM, Vogt C, Tinsay AM, Schmidt TE, Tessier KM, Erickson BK. An innovative medical school curriculum to address human papillomavirus vaccine hesitancy. Vaccine 2018;36(26):3830-5. https://doi.org/10.1016/j.vaccine.2018.05.014 